\title{
In-Vitro Growth Enhancement of Cedrela odorata L. using Benzyl Amino Purine and A-Naphthalene Acetic Acid
}

\author{
*J.O Afolabi, A.O Asonibare, O.A Onawumi and E.O. Oyetunde \\ Forestry Research Institute of Nigeria, Jericho Hills, Ibadan \\ [Corresponding Author: E-mail: olujames58@gmail.com; D: +2347033220092]
}

\section{ABSTRACT}

Studies were conducted in order to develop protocol for mass-production of Cedrela odorata seedlings. Clean-plantlets were initiated on four media at full and half strengths. Shoot-regeneration consisted two media types (Murashige \& Skoog (MS) and Woody Plant Medium (WPM)) and four Benzyl Amino Purine (BAP) concentrations: 0.0, 1.0, 2.0 and $3.0 \mathrm{mg} / \mathrm{l}$. Root-induction involved three MS media strengths $(25,50$ and $100 \%$ basal salts) and two Naphthalene Acetic Acid (NAA) levels (0.0 and $0.5 \mathrm{mg} / \mathrm{l})$ all in factorial combinations and laid out in completely randomised design (CRD). The results at initiation showed that MS at full strength enhanced in vitro seeds growth better in terms of root lengths $(6.50 \mathrm{~cm})$ and number of leaves (7.6) while WPM gave better shoot length $(6.24 \mathrm{~cm})$ at 3 Week after inoculation (WAI). Shoots were best regenerated on MS basal medium supplemented with $1.0 \mathrm{mg} / \mathrm{l} \mathrm{BAP}$ for shoot length at 4 WAI while the effects of BAP levels were comparable but higher than control for number of leaves and axillary shoots. Highest number of roots (3.92) induced and root length $(2.93 \mathrm{~cm}$ ) obtained were from $100 \%$ MS medium at 8 WAI. Hence, MS medium (100\% basal salt) with $1.0 \mathrm{mg} / \mathrm{l} \mathrm{BAP}$ with or without $0.5 \mathrm{mg} / \mathrm{l} \mathrm{NAA}$ are considered suitable protocol for in vitro propagation of $C$. odorata.

Keywords: Clean-plantlets, Benzyl amino purine, Root-induction, Shoot-regeneration

\section{INTRODUCTION}

Cedrela odorata L, commonly known as Cedar Wood belongs to family Meliaceae and originated from the tropical America (Pennington and Muellner 2010; Rolando et al., 2011). The species is one of the most valuable world's timber and highly overexploited. Every part of the tree has been reported for various medicinal uses while it is useful for agroforestry, afforestation and furniture making. The species is attacked by a pest called Hypsipyla and consequently becomes so scarce and has been listed among the endangered tree species (Carlos et al., 2002; Perez and Esquivel 2008). Conventional method of propagating such trees like this with long gestation period is not adequate to establish its commercial plantation (Perez et al., 2006; Carola and Michael 2013). Therefore, it is expedient and needful to propagate the tree species in large numbers through alternative means in order to catch up with its high demand and avoid its extinction (Pennington and Muellner 2010; Ken 2019).
Tissue culture technique (in vitro propagation) is a modern method of propagating woody trees and has provided a rapid means of multiplying them in a shorter time under limited space with ex situ conservation of their germplasms. However, tissue culturing of woody plant is noted to be difficult owing to its slow regeneration ability (Husain et al., 2008; Nitish and Reddy 2011; Rolando et al., 2011). Perez et al. (2002) reported that in vitro propagation of $C$. odorata has not been thoroughly done. Although, there have been reports on the use of its nodal segments and apical buds collected from juvenile plants raised from seeds (Perez et al., 2002; Maruyama, 2006). Notwithstanding, it has been observed that $C$. odorata is recalcitrant to tissue culture as a result of oxidative processes of fungi and bacteria after disinfection which leads to a less morphogenic response of the explants. Such challenges can be overcome by supplementing the media with cytokinins and auxins at different rate (Perez et al., 2002; Rolando et al., 2011). Consequently, the aims of this study was to assess the effect of 
different media supplemented with growth regulators on growth performance of $C$. odorata in order to ensure its in vitro mass propagation in Nigeria.

\section{MATERIALS AND METHODS \\ Study Location}

The research was conducted in the Biotechnology section, Bioscience Department, Forestry Research Institute of Nigeria (FRIN), Ibadan, located on the longitude $07023^{\prime} 18 \mathrm{~N}$ to 07023'43N and latitude $03^{\circ} 51^{\prime} 20 \mathrm{E}$ to 032'ㄴㄹㅡ (FRIN, 2018, unpublished). The location is $199 \mathrm{~m}$ above sea level and the climate is tropical. It has average annual temperature of $25.9{ }^{\circ} \mathrm{C}$ while precipitation is about $1467 \mathrm{~mm}$ annually (CDO, 2019)

\section{Experimental Design and Treatments}

The following sequence of experiments were conducted to achieve in vitro regeneration of $C$. odorata plantlets: culture initiation, shoot regeneration and root induction. The culture initiation comprised of $4 \times 2$ factorial treatments with five replicates. The first factor were four media types (Murashige and Skoog (MS), Driver and Kuniyuki (DKW), Preece $(P)$ and Woody Plant Medium (WPM)) while second factor were two media strengths (Full and half i.e. 100 and $50 \%$ of their basal salts, respectively). Shoot regeneration experiment consist of $2 \times 4$ factorial treatments with six replicates. First factor for shoot regeneration were two media types (MS and WPM) while second factor were benzyl amino purine (BAP) levels (0.0 (control), 1.0, 2.0 and $3.0 \mathrm{mg} / \mathrm{l})$. The rooting experiment involved 3 $x 2$ factorial treatments with six replicates. The first factor for root induction were three MS media strengths $(25,50$ and $100 \%$ basal salts) while the second factor were two levels of naphthalene acetic acid (NAA) $(0.0$ (control) and $0.5 \mathrm{mg} / \mathrm{l})$. All the experiments were laid out in a completely randomised design (CRD).

\section{Media Preparation and Explant Sterilization} All the media were prepared in accordance with standard procedures, MS; (Murashige and
Skoog, 1962), WPM; (Lloyd and McCown, 1980), DKW; (Driver and Kuniyuki, 1984; McGranahan et al., 1987) and Preece; (Preece et al., 1989). The growth regulators were added according to the treatments and experiments. The media $\mathrm{pH}$ was all adjusted to 5.8, add up and gelled with $9.0 \mathrm{~g} / \mathrm{l}$ of agar (Sigma Aldrich, Lot 83112) then 20 $\mathrm{ml}$ of prepared media was dispensed per tube and autoclaved for 15 minutes at $121^{\circ} \mathrm{C}$ and 15 psi. Matured seed of $C$. odorata were collected from Forestry Research Institute of Nigeria, Arboretum. The seeds were de-winged and sterilized as follows: the seeds were dipped in fungicide mixture $(5 \mathrm{~g} / \mathrm{l}$ Z-force $+5 \mathrm{~g} / \mathrm{l}$ cibaplus + $0.4 \mathrm{~g} / \mathrm{l}$ amoxicillin) for 60 minutes, rinsed thrice with sterile distilled water then dipped in $70 \%$ ethanol for 5 minutes. The seeds were rinsed thrice then dipped in $10 \%$ hypochlorite solution containing two drops of tween 20. The seeds were then rinsed four times and blotted on sterilized petri-dish laid filter paper before inoculation. The shoot tips and nodal segment of the seed plantlets were subcultured 4 Weeks after inoculation (WAI) into the shoot regeneration media. After 5 WAI of growth, the plantlets were subcultured into root induction media.

\section{Data Collection and Analysis}

Data collected included shoot and root lengths (cm) with the aid of a meter rule. Number of leaves and roots were determined by manually counting plantlets. Replicates were subjected to analysis of variance while means for the different treatments were separated using Duncan Multiple Range Test at 95\% confidence level.

\section{RESULTS}

\section{Seed Culture Initiation}

The results of in-vitro propagation of $C$. odorata seeds using different media types and strengths at 3 weeks after inoculation (WAI) are presented in Table 1. There was no significant difference $(p>0.05)$ in the main effect of the factors and their interaction on shoot length of the plantlets. The shoot length ranged from the highest $(6.24 \mathrm{~cm})$ in WPM at full strength to the lowest $(4.38 \mathrm{~cm})$ in 
MS medium at half strength. At the same time, effect of media strengths and interactive effect of both factors on root lengths and number of leaves were significantly different $(p<0.05)$. The average root lengths $(5.07 \mathrm{~cm})$ and number of leaves $(7)$ produced from full strength media were significantly higher than those of half strength media having $4.01 \mathrm{~cm}$ and 5.5 , respectively at 3 WAl (Figures 1 and 2). The average root length
$(6.50 \mathrm{~cm})$ from full strength MS medium was significantly higher than observed for Preece $(4.20 \mathrm{~cm})$, WPM $(3.80 \mathrm{~cm})$ and half strength MS $(3.14 \mathrm{~cm})$ media but comparable to WPM and DKW at full strength (Table 1). Similarly, average number of leaves of 7.6 obtained from MS at full strength was higher than MS at half strength but similar to other media irrespective of their strength (Table 1).

Table 1: Effect of Different Media and Strengths on Growth of in vitro Seed Germination of Cedrela odorata at 3 (WAl)

\begin{tabular}{|c|c|c|c|c|}
\hline \multicolumn{2}{|c|}{ FACTORS } & \multirow{2}{*}{$\begin{array}{c}\text { SHOOT } \\
\text { LENGTH } \\
\text { (CM) }\end{array}$} & \multirow{2}{*}{$\begin{array}{l}\text { ROOT } \\
\text { LENGTH } \\
\text { (CM) }\end{array}$} & \multirow[b]{2}{*}{$\begin{array}{l}\text { NUMBER OF } \\
\text { LEAVES }\end{array}$} \\
\hline MEDIA TYPE & $\begin{array}{l}\text { MEDIA } \\
\text { STRENGTH }\end{array}$ & & & \\
\hline \multirow{2}{*}{$\begin{array}{l}\text { MURASHIGE AND } \\
\text { SKOOG }\end{array}$} & Full & 6.16 & $6.50 a$ & $7.6 a$ \\
\hline & Half & 4.38 & $3.14 b$ & $3.6 \mathrm{~b}$ \\
\hline PREECE & $\begin{array}{l}\text { Full } \\
\text { Half }\end{array}$ & $\begin{array}{l}5.12 \\
5.60\end{array}$ & $\begin{array}{l}4.50 \mathrm{ab} \\
4.20 \mathrm{~b}\end{array}$ & $\begin{array}{l}5.2 \mathrm{ab} \\
6.0 \mathrm{ab}\end{array}$ \\
\hline \multirow{2}{*}{$\begin{array}{l}\text { WOODY PLANT } \\
\text { MEDIUM }\end{array}$} & Full & 6.24 & 4.76ab & $7.6 a$ \\
\hline & Half & 5.90 & $3.80 \mathrm{~b}$ & $7.2 \mathrm{a}$ \\
\hline DKW & $\begin{array}{l}\text { Full } \\
\text { Half }\end{array}$ & $\begin{array}{l}6.06 \\
5.40\end{array}$ & $\begin{array}{l}4.50 \mathrm{ab} \\
4.90 \mathrm{ab}\end{array}$ & $\begin{array}{l}7.6 \mathrm{a} \\
5.2 \mathrm{ab}\end{array}$ \\
\hline \multicolumn{5}{|l|}{ L.S.D @ $p \leq 0.05$} \\
\hline Media types & & 1.12 & 1.3 & 1.79 \\
\hline Media strength & & 0.79 & $0.9^{*}$ & $1.26^{*}$ \\
\hline Media types $\mathrm{x}$ Med & rengths & 1.59 & $1.84^{*}$ & $2.53^{*}$ \\
\hline
\end{tabular}

* indicates means difference significant at $p \leq 0.05,(n=40)$ 


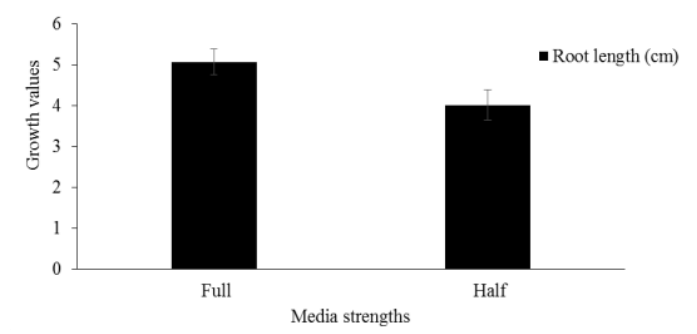

Figure 1: Effect of media strengths on root length of in vitro propagated seeds of Cedrela odorata at 3 WAl; $(n=20)$

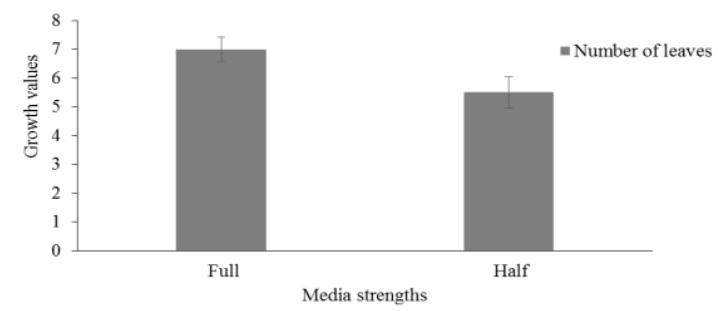

Figure 2: Effect of media strengths on number of leaves of in vitro propagated seeds of Cedrela odorata at 3 WAI.

\section{Shoot Regeneration}

\section{Shoot Length of Regenerated C. odorata Plantlets}

The effect of media types (MS and WPM) and BAP levels $(0.0,1.0,2.0$ and $3.0 \mathrm{mg} / \mathrm{l})$ was assessed on shoot regeneration of $C$. odorata. Plantlet growth from both media (MS and WPM) were similar in shoot length while BAP levels had comparable effects on the same parameter at 2 WAI (Table 2). The average shoot length as affected by BAP ranged from $1.96 \mathrm{~cm}$ to $2.48 \mathrm{~cm}$ from media added, $3.0 \mathrm{mg} / \mathrm{l}$ and $1.0 \mathrm{mg} / \mathrm{l}$, respectively. The interactive effect of the two factors was not significantly different $(p>0.05)$ on the shoot length at same period (Table 2).

Results at 4 WAI indicated that there was significant difference $(p \leq 0.05)$ in the main effects of the media types and BAP levels but not their interaction on shoot length (Table 2). Shoot length of $2.66 \mathrm{~cm}$ from MS medium was significantly higher $(p \leq 0.05)$ than $2.11 \mathrm{~cm}$ obtained from WPM (Figure 3). The average effect of supplementing the media with BAP indicated that shoot length $(2.79 \mathrm{~cm})$ from medium added $1.0 \mathrm{mg}$ BAP/l was significantly different from media added $3.0 \mathrm{mg} \mathrm{BAP/L}$ and 0.0 $\mathrm{mg} \mathrm{BAP/l}$ (control) whereas, similar to $2.0 \mathrm{mg}$ BAP/I medium (Figure 4). The obtained average shoot length of $2.39 \mathrm{~cm}$ obtained from using 2.0 mg BAP/l was however not significantly different ( $p>0.05$ ) from $2.29 \mathrm{~cm}$ and $2.06 \mathrm{~cm}$ obtained from $3.0 \mathrm{mg} \mathrm{BAP} / \mathrm{l}$ and $0.0 \mathrm{mg} \mathrm{BAP} / \mathrm{l}$, respectively (Figure 4).

\section{Root Length of Regenerated C. odorata Plantlets}

The results of root length of the sub-cultured $C$. odorata plantlets as influenced by media types and BAP levels showed that there was no significant difference $(p>0.05)$ among the media types as well as interaction between the media types and BAP levels at 2 WAI (Table 2). Conversely, significant difference $(p \leq 0.05)$ was observed between the mean root lengths as affected by BAP levels at the same period (Table 2). Using the media without BAP $(0.0 \mathrm{mg} / \mathrm{l})$ gave significantly higher number of roots compared with other media with varying levels of BAP from which no roots were produced at 2 WAI (Figure 5).

By 4 WAI, mean differences within the factors and between their interactions were observed to be significantly different (Table 2). Longer roots $(0.94 \mathrm{~cm})$ were produced using WPM compared with MS $(0.44 \mathrm{~cm})$ medium (Figure 3). Similarly, the effects of BAP followed the same pattern as in 2 WAI. Media with no BAP addition produced longer root length compared with others (Figure 5). The interactive effects of the factors on plantlets growth showed that using WPM with no BAP produced significantly longer root $(3.75 \mathrm{~cm})$ than MS $(1.77 \mathrm{~cm})$ without BAP (Table 2). 


\section{Number of Leaves of Regenerated C. odorata Plantlets}

The effect of media types and BAP on number of leaves of $C$. odorata presented in Table 3 showed that mean differences within the factors and their interaction were significantly different $(p \leq 0.05)$ at 2 and 4 WAl. Higher number of leaves were produced using MS medium $(2.61,4.29)$ compared with WPM $(1.26,1.74)$ at 2 and 4 WAI, respectively (Figure 6 )

Considering the addition of BAP, irrespective of the media used, higher average number of leaves
(2.61) obtained using $1.0 \mathrm{mg} / \mathrm{l}$ BAP was significantly higher $(\mathrm{p} \leq 0.05)$ compared to 1.13 and 1.79 from control $(0.0 \mathrm{mg} / \mathrm{BAP})$ and $3 \mathrm{mg} / \mathrm{l}$ BAP at 2 WAl. However, at 4 WAl, the use of 3 $\mathrm{mg} / \mathrm{l}$ BAP produced more leaves (4.0) than control (1.44) but similar to 3.33 and 3.29 obtained from media added 1.0 and $2.0 \mathrm{mg} / \mathrm{l}$ BAP respectively (Figure 7 . The interactive effects of media and BAP on number of leaves at 4 WAI indicated that MS medium with $3.0 \mathrm{mg} / \mathrm{BAP}$ produced comparable number of leaves (5.86) to MS medium (5.0 and 4.57) with 1.0 and $2.0 \mathrm{mg} / \mathrm{l}$ BAP addition (Table 3 )

Table 2: Interactive effects of media types and bap levels on shoot and root length of $C$. odorata at 4 WAI

\begin{tabular}{lccccc}
\hline \multicolumn{2}{c}{ FACTORS } & \multicolumn{2}{c}{ SHOOT LENGTH (cm) } & \multicolumn{2}{c}{ ROOT LENGTH (cm) } \\
MEDIA & Bap (mg/l) & 2 WAI & 4 WAI & 2 WAI & 4 WAI \\
\hline MS & & & & & \\
& 0.0 & 1.9 & 1.94 & 0.93 & $1.77 \mathrm{~b}$ \\
& 1.0 & 2.51 & 3.14 & 0.00 & $0.00 \mathrm{c}$ \\
& 2.0 & 2.17 & 2.83 & 0.00 & $0.00 \mathrm{c}$ \\
& 3.0 & 2.13 & 2.71 & 0.00 & $0.00 \mathrm{c}$ \\
WPM & & & & & \\
& 0.0 & 2.07 & 2.18 & 1.67 & $3.75 \mathrm{a}$ \\
& 1.0 & 2.45 & 2.43 & 0.00 & $0.00 \mathrm{c}$ \\
& 2.0 & 1.94 & 1.96 & 0.00 & $0.00 \mathrm{c}$ \\
& 3.0 & 1.79 & 1.86 & 0.00 & $0.00 \mathrm{c}$
\end{tabular}

L.S.D @ $p \leq 0.05$

\begin{tabular}{llccc} 
Media types & 0.31 & $0.33^{* *}$ & 0.33 & $0.40^{*}$ \\
Bap levels & 0.43 & $0.47^{*}$ & $0.47^{* *}$ & $0.56^{* *}$ \\
Media x Bap levels & 0.61 & 0.67 & 0.67 & $0.79^{* * *}$ \\
\hline
\end{tabular}

${ }^{*}$ and ${ }^{* \star}$ indicate means difference significant at $p \leq 0.05$ and $p \leq 0.01$. WAl: Weeks after inoculation.

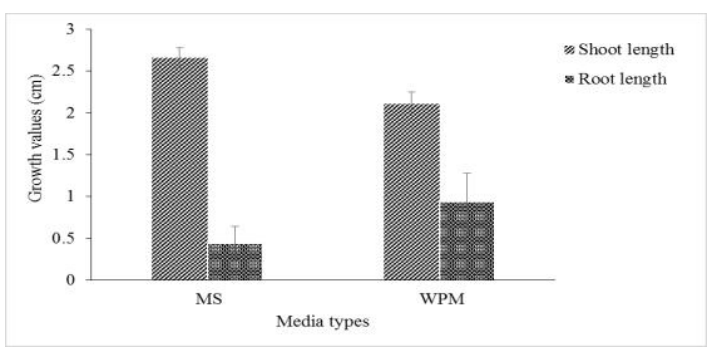

Figure 3: Effect of media types on shoot and root length of sub-cultured plantlets of $\mathrm{C}$. odorata at 4 WAl.
Number of Roots of Regenerated C. odorata Plantlets

The results of effect of BAP levels and media types as well as their interaction on number of roots of sub-cultured $\mathrm{C}$. odorata plantlets are shown in Table 3. It was observed that only mean difference of BAP levels was significant at 2 and 4 WAl. Roots were only formed when the plantlets were inoculated on media with no BAP addition with average of 0.99 and 1.29 roots at 2 and 4 WAl (Figure 8) 


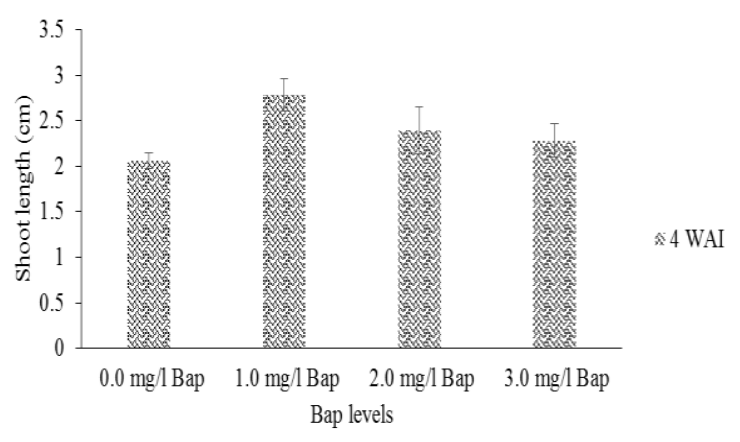

Figure 4: Effect of BAP on shoot length of subcultured plantlets of $C$. odorata at 4 WAI

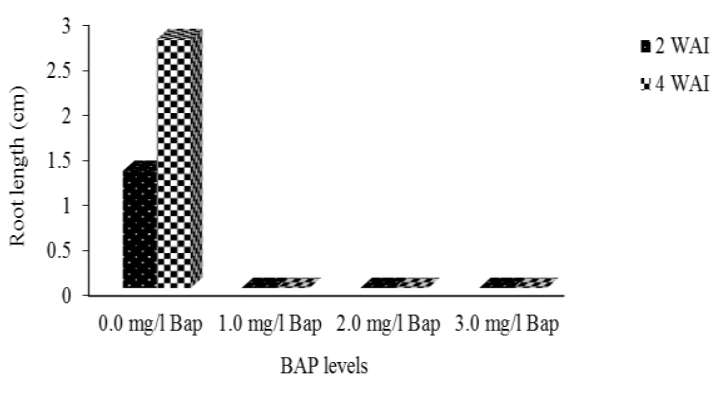

Figure 5: Effect of BAP on root length of subcultured plantlets of $C$. odorata at 4 WAI.

Table 3: Interactive effects of media types and bap levels on number of leaves, roots and axillary shoots of C. odorata at 4 WAI

\begin{tabular}{|c|c|c|c|c|c|c|}
\hline \multicolumn{2}{|c|}{ FACTORS } & \multicolumn{2}{|c|}{ NUMBER OF LEAVE } & \multicolumn{2}{|c|}{ NUMBER OF ROOTS } & \multirow{2}{*}{$\begin{array}{c}\text { NUMBER OF } \\
\text { AXILLARY SHOOTS } \\
4 \text { WAI }\end{array}$} \\
\hline MEDIA & BAP (mg/l) & 2 WAI & 4 WAl & 2 WAl & 4 WAl & \\
\hline \multicolumn{7}{|l|}{ MS } \\
\hline & 0.0 & 1.43 & $1.71 b$ & 1.14 & 1.43 & $0.00 \mathrm{~b}$ \\
\hline & 1.0 & 3.71 & $5.00 \mathrm{a}$ & 0.00 & 0.00 & $2.00 a$ \\
\hline & 2.0 & 3.00 & $4.57 a$ & 0.00 & 0.00 & $1.71 a$ \\
\hline & 3.0 & 2.29 & $5.86 a$ & 0.00 & 0.00 & $2.14 a$ \\
\hline \multicolumn{7}{|l|}{ WPM } \\
\hline & 0.0 & 0.83 & $1.17 b$ & 0.83 & 1.17 & $0.00 b$ \\
\hline & 1.0 & 1.50 & $1.67 b$ & 0.00 & 0.00 & $0.00 \mathrm{~b}$ \\
\hline & 2.0 & 1.43 & $2.00 \mathrm{~b}$ & 0.00 & 0.00 & $0.00 \mathrm{~b}$ \\
\hline & 3.0 & 1.29 & $2.14 b$ & 0.00 & 0.00 & $0.29 b$ \\
\hline \multicolumn{7}{|c|}{ L.S.D @ p $\leq 0.05$} \\
\hline Media t & & $0.54^{* *}$ & $0.76^{* *}$ & 0.22 & 0.23 & $0.33^{* *}$ \\
\hline Bap lev & & $0.76^{* *}$ & $1.07^{* *}$ & $0.31^{* *}$ & $0.33^{* *}$ & $0.47^{* *}$ \\
\hline Media X & ap levels & 1.08 & $1.51^{*}$ & 0.45 & 0.46 & $0.67^{* *}$ \\
\hline
\end{tabular}

${ }^{*}$ and ${ }^{* *}$ indicate means difference significant at $p \leq 0.05$ and $p \leq 0.01$; WAl: Weeks after inoculation 


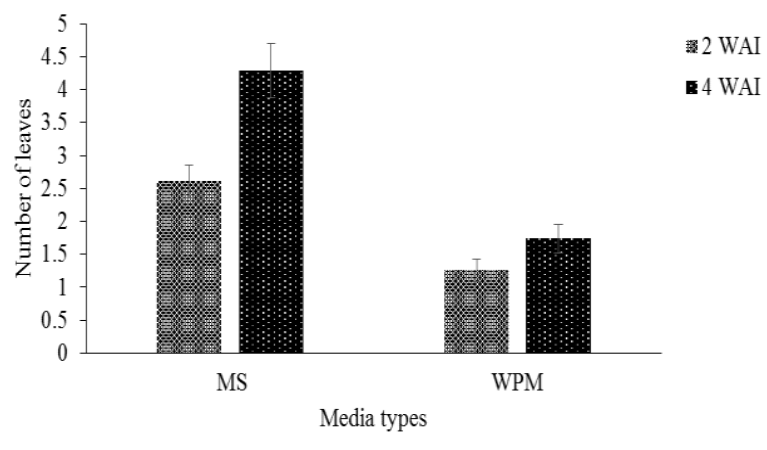

Figure 6: Effect of media types on number of leaves of sub-cultured plantlets of $C$. odorata at 4 WAI.

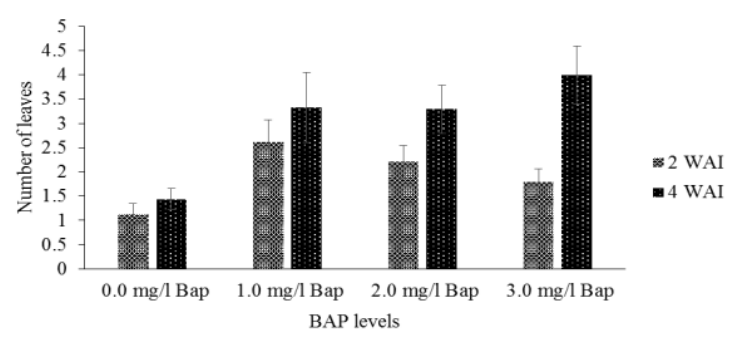

Figure 7: Effect of BAP on number of leaves of sub-cultured plantlets of $C$. odorata at 4 WAl.

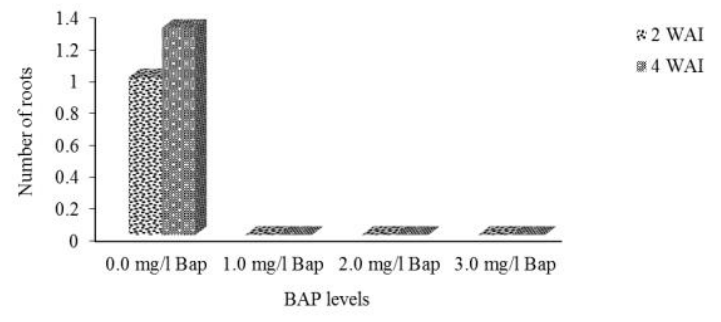

Figure 8: Effect of BAP on number of roots of sub-cultured plantlets of $C$. odorata at 4 WAl.

Number of Axillary Shoots of Regenerated $C$. odorata Plantlets

The results of the axillary shoots produced as influenced by different media and BAP levels are presented in Table 3. Higher axillary shoots (1.46) produced from MS medium was higher than that of WPM (0.071) at 4 WAI (Figure 9).

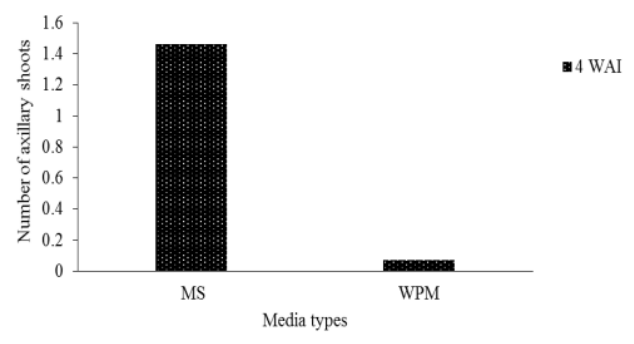

Figure 9: Effect of media types on number of axillary shoot of sub-cultured plantlets of $C$. odorata at 4 WAI

\section{Root induction}

The results of effect of different concentration of MS medium with or without $0.5 \mathrm{mg} / \mathrm{l} \mathrm{NAA}$ is presented in Table 4. It was observed that the effect of MS medium strength was not significantly different $(p>0.05)$ on number of roots at 4 and 6 weeks after inoculation (WAI). Similarly, the mean difference of NAA levels and interactive effect of the factors were not significantly different on number of roots and root length at 4, 6 and 8 WAl. However, there was significant different $(p \leq 0.05)$ in the effect of MS strength on number of roots at $8 \mathrm{WAI}$ and on root length across the successive growth weeks (Table 4 and Plate 1). The average of 3.92 roots obtained from $100 \%$ MS medium was higher than 0.33 and 0.33 from $50 \%$ and $25 \%$ MS medium, respectively (Figure 10 and Plate 1). Through 4, 6 and 8 weeks' period after inoculation, a significant root length of $1.4,2.65$ and $2.93 \mathrm{~cm}$ were observed in $100 \%$ MS medium higher than 0.13 , 0.13 and $0.22 \mathrm{~cm}$ from $25 \% \mathrm{MS}$ medium and $0.07,0.07$ and $0.07 \mathrm{~cm}$ from 50\% MS medium, respectively (Figure 11 and Plate 1). 
Afolabi et al. In-Vitro Growth Enhancement of Cedrela odorata L. using Benzyl Amino Purine...

Table 4: Effect of media strength and NAA levels on root growth of $C$. odorata at 8 WAI

\begin{tabular}{|c|c|c|c|c|c|c|c|}
\hline \multicolumn{2}{|c|}{ FACTORS } & \multicolumn{3}{|c|}{ NUMBER OF ROOTS } & \multicolumn{3}{|c|}{ ROOT LENGTH (CM) } \\
\hline $\begin{array}{c}\text { MS STRENGTH } \\
(\%)\end{array}$ & NAA (mg/l) & 4 WAI & 6 WAI & 8 WAl & 4 WAI & $6 \mathrm{WAl}$ & 8 WAI \\
\hline \multirow[t]{2}{*}{25} & 0.0 & 0.17 & 0.17 & 0.17 & 0.25 & 0.27 & 0.27 \\
\hline & 0.5 & 0 & 0 & 0.5 & 0.0 & 0.0 & 0.17 \\
\hline \multirow[t]{2}{*}{50} & 0.0 & 0 & 0 & 0 & 0.0 & 0.0 & 0.0 \\
\hline & 0.5 & 0.5 & 0.67 & 0.67 & 0.13 & 0.15 & 0.17 \\
\hline \multirow[t]{2}{*}{100} & 0.0 & 0.83 & 1 & 2 & 1.57 & 2.97 & 3.13 \\
\hline & 0.5 & 3.33 & 4 & 5.83 & 1.23 & 2.33 & 2.73 \\
\hline \multicolumn{8}{|c|}{ L.S.D @ $p \leq 0.05$} \\
\hline \multicolumn{2}{|c|}{ Media strength (MST) } & 2.0 & 2.31 & $2.72^{*}$ & $0.99^{*}$ & $1.52^{*}$ & $1.69^{*}$ \\
\hline \multicolumn{2}{|c|}{ NAA levels (NL) } & 1.63 & 1.87 & 2.22 & 0.81 & 1.24 & 1.38 \\
\hline \multicolumn{2}{|l|}{ MST X NL } & 2.83 & 3.27 & 3.84 & 1.40 & 2.15 & 2.39 \\
\hline
\end{tabular}

* indicates means difference significant at $p \leq 0.05$ WAl: Weeks after inoculation

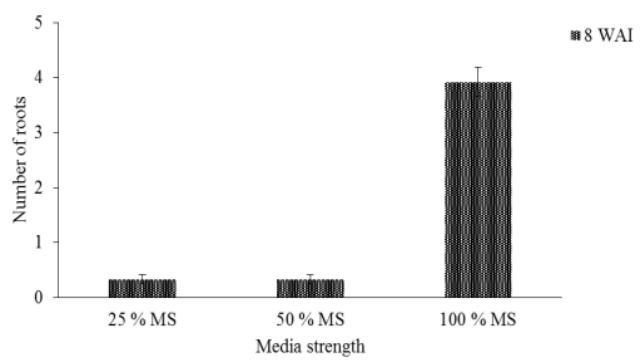

Figure 10: Effect of media strength on number of roots of sub-cultured plantlets of $C$. odorata at 8 WAI.

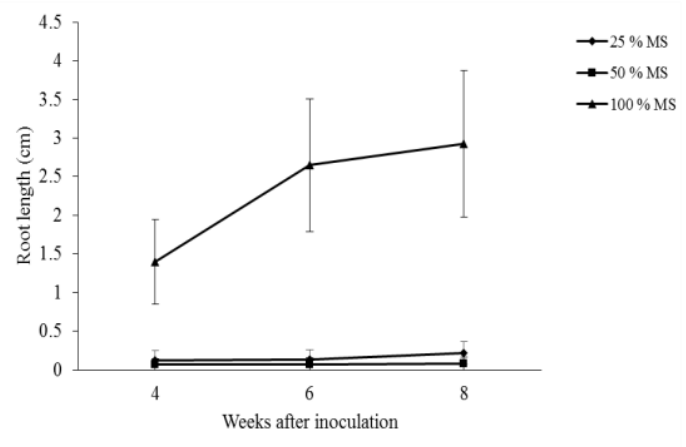

Figure 11: Effect of media strength on root length of sub-cultured plantlets of $C$. odorata at successive growth weeks.

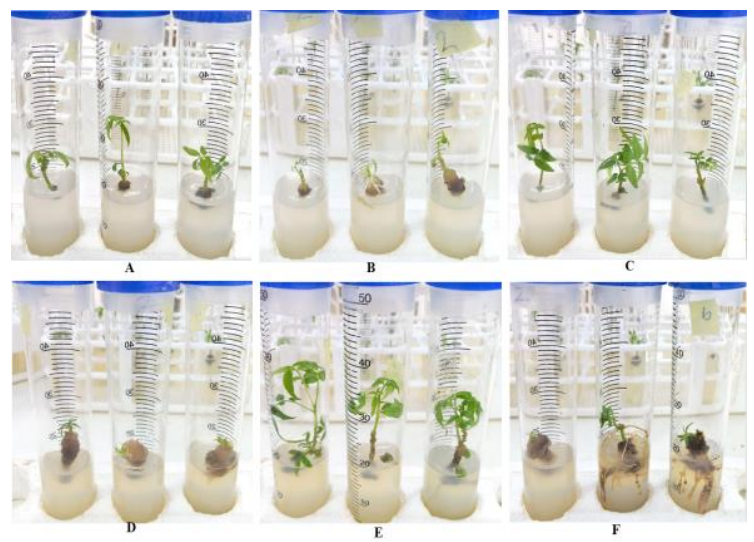

Plate 1: Effect of MS media strength and NAA level on root growth of $C$. odorata at 8 weeks after inoculation

A: MS $25 \%$ basal salt $/ 0.0 \mathrm{mg} / \mathrm{l}$ NAA; $\mathbf{B}$ : MS $25 \%$ basal salt/0.5 mg/l NAA; C: MS $50 \%$ basal salt/0.0 mg/l NAA; D: MS $50 \%$ basal salt/0.5 mg/l NAA; E: MS $100 \%$ basal salt/0.0 mg/l NAA and F: MS 100\% basal salt/0.5 mg/l NAA

\section{DISCUSSION}

\section{Culture Initiation}

Four media (MS, Preece, WPM and DKW) at two strengths (Half and full basal salts) were considered for in-vitro seed germination of $C$. odorata. The similarity observed in the effect of media types on shoot and root length and number 
of leaves of the seed plantlets (Table 1), indicated that any of the media could be used for the culture initiation of $C$. odorata from seeds. The observed similarity could be attributed to the viability of the seeds which resulted into even germination and growth across the media. It was reported that viability of $C$. odorata seeds drops quickly after about two months of collection (Jones, 1967) while seed viability is a contributor to poor seed germination of many wild fruit tree species (Akinnifesi et al., 2007). In this study, freshly collected seeds of $C$. odorata were used hence, the results obtained. This result differs from that of Castillo-Martinez (2017), who observed that MS medium complemented with activated charcoal provided best germination support for $\mathrm{C}$. odorata seeds among other media (MS, WPM, Gambor Medium, distilled water, Schenk and Hildebrand) used with or without activated charcoal.

Meanwhile, the significantly higher growth obtained from full strength media (Figure 1 and 2) showed that the plantlet growth required more nutrient than available in half strength media. Seeds can contain sufficient nutrient to allow for germination and considerable increase in plant size (Mcdonald, 1994). However, the small amount of nutrient component of $C$. odorata seed would have been quickly exhausted at the onset of root emergence. Higher root length coupled with the species rapid growth could have resulted into more uptake of nutrients available in the full strength media. Roots are vital organ that supply water and nutrients to growing seedlings (Fageria et al., 2014). It was reported that, vigorous root growth ensured efficient acquisition of macro- and micronutrients while high root length to shoot dry matter ratio was stated to favour high macronutrient concentrations in the shoots of spring wheat which was perceived to be important for later plant development (Wang et al., 2016).

The obtained results of interaction between media types and media strength in which better support was provided by both WPM and MS each at full strength on all the parameters (Table 1) revealed that both media performed to the same extent in terms of in-vitro seed propagation. This result could be attributed to the variation in the composition of these media when compared with DKW and Preece. Mineral composition of basal medium was stated to be a significant factor in the morphogenic response of in vitro $C$. odorata plants (Perez, 2005)

\section{Shoot Regeneration}

MS and WPM supplemented with four BAP levels in a factorial arrangement were considered in this stage. The better results obtained from MS medium in terms of shoot length (Figure 3), Number of leaves (Figure 6) and number of axillary shoots (Figure 9) at 4 WAI indicated that MS medium was better in supporting the shoot growth of $C$. odorata than did by WPM medium. Higher concentration of some essential elements such as nitrogen and presence of some micro elements like cobalt, iron and iodine in MS medium could have accounted for observed shoot growth (Mohammad et al., 2014). This result was similar to that of Marzi (2013) who obtained optimal in vitro development of date palm (cv. '16-bis') in terms of leaf length and greening, and root number and length when cultured on MS medium compared to WPM and Nitsch media.

The higher shoot length obtained when $1 \mathrm{mg} / \mathrm{l}$ BAP was used irrespective of the media at 4 WAI (Figure 4) showed that increasing the BAP concentration from 2 to $3 \mathrm{mg} / \mathrm{l}$ might have exerted inhibitory effect on the elongation of the species plantlets in vitro. This was evident in the comparable number of leaves and axillary shoot produced even at $3.0 \mathrm{mg} / \mathrm{l}$ BAP across the media at 4 WAI (Table 3). This result could be supported by the findings of Schottz et al. (2007) that high concentrations of BAP $(20 \mu \mathrm{M})$ and N6-[2isopentenyl] adenine (2-iP) $(2 \mu \mathrm{M})$ caused a significant reduction in plant development and internodal length of Swietenia macrophylla which 
affected the multiplication rate. The results also corroborated that of Seema \& Vijaya, (2015) where BAP applied at lower concentration $(0.5$ $\mathrm{mg} / \mathrm{l})$ gave best shoot bud induction and multiplication on Clerodendrum serratum L. whereas, similarity and declining effect was observed at higher concentrations.

The growth of roots from plantlets on media without BAP addition $(0.0 \mathrm{mg} / \mathrm{l})$ both in numbers (Figure 8) and lengths (Figure 5) revealed that root induction by $C$. odorata may not require the use of plant growth regulators (PGR). These results correlated with the report of Perez et al. (2002) that root induction from node segments derived from in vitro-germinated $C$. odorata seeds was inhibited when BAP was added to the basal medium at 2.2 and $6.5 \mu \mathrm{M}$. Moreover, it was closely related to that of Olorode et al. (2018) who observed that $C$. odorata plantlets developed shoots and roots 13 days after inoculation from media free of Plant Growth Regulator (PGR).

\section{Root induction}

The use of MS medium at different strengths with or without NAA had significant effect on root induction of $C$. odorata (Table 4). The obtained highest number of roots (Figure 10) and longest root lengths (Figure 11) from MS medium (100\% basal salts) at 8 WAl showed that high concentration of nutrients in full MS basal salts favoured root induction of the species than in $50 \%$ and $25 \%$ basal salts. This result could be ascribed to higher nutrient availability and uptake in the MS medium with $100 \%$ basal salts. Concentration of salts or other osmotically active compounds that constitute the nutrient medium might have triggered the activation of metabolic pathways that culminated in root induction and development (Elequisandra et al., 2017).

The comparable growth of roots from the media irrespective of strength with or without $0.5 \mathrm{mg} / \mathrm{l}$ NAA (Table 4) revealed that C. odorata root induction was favoured by low concentration of NAA. Auxins like NAA is required by most plant cells for division and root initiation but can suppress morphogenesis at high concentrations. It was clearly shown by the result of this study that plantlets from media with no NAA had better leave formation and overall growth whereas more roots were formed at low NAA $(0.5 \mathrm{mg} / \mathrm{l})$ addition (Plate 1). Similar result was reported on Curculigo latifolia when highest percentage of root induction and longer roots were obtained from MS devoid of growth regulators while medium supplemented with $0.25 \mathrm{mg} / \mathrm{l}$ indole-3-butyric acid (IBA) produced more number of roots (Babaei et al., 2014). Cedrela fissilis was also reported to have rooted on MS medium with or without $2.5 \mu \mathrm{M}$ IBA supplement though on half strength (Nunes et al., 2002).

\section{CONCLUSION}

This study was undertaken in order to develop in vitro protocol for mass production of Cedrela odorata. From the results, the best supporting medium for culture initiation of Cedrela odorata seeds is any of Woody Plant Medium or Murashige and Skoog medium at full strength. The shoot regeneration and rooting of the subcultured plantlets were best achieved on 100\% MS medium supplemented with $1.0 \mathrm{mg} / \mathrm{l} \mathrm{BAP}$ with or without $0.5 \mathrm{mg} / \mathrm{lNA}$. Consequently, the developed protocol is hereby recommended for in vitro mass propagation of the species while further study on the area of acclimatization is required.

\section{REFERENCES}

Akinnifesi, F.K., Sileshi, G., Mkonda, A., Ajayi, O.C., Mhango, J. \& Chilanga, T. (2007). Germplasm supply, propagation and nursery management of Miombo fruit trees. In: Akinnifesi, F.K., Leakey, R.R.B., Sileshi, G., Ajaji, O., Tchoundjeu, Z., Matakala, P. and Kwesiga, F. (Eds) Indigenous Fruit Trees in the Tropics: Domestication, Utilization and Commercialization, CABI publishing, UK. pp 341-368.

Babaei, N., Psyquay N.A., Saleh, A.G. \& Abdullah, T.L. (2014). An efficient in vitro 


\section{Nigerian Journal of Basic and Applied Science (June, 2021), 29(1): 71-82}

plantlet regeneration from shoot tip cultures of Curculigo latifolia, a medicinal plant. The Scientific World Journal, (2014):9.

Carlos, N., Sheila, W. \& Marvin, H. (2002). The tree Cedrela odorata (Meliaceae): A morphologically subdivided species in Costal Rica. Journal of Tropical Biology, 50(1): 21-29.

Carola, P. \& Michael, W. (2013). Intercropping Cedrela odorata with shrubby crop species to reduce infestation with Hypsiphyla grandella and improve the quality of the timber. International Schorlarly Research Notices Forestry, (2013):10.

Castillo-Martinez, C.R. (2017). In vitro germination seeds of Cedrela odorata L. of extinted genotypes. Agro Productividad, 10(8): 53-58

Climate-data.org (CDO) (2019). Ibadan climate (Nigeria). https://en.climate data.org/africa/nigeria/oyo/ibadan-529/. Assessed on 14th March, 2021.

Driver, J.A \& Kuniyuki, A.H. (1984). In Vitro propagation of Paradox Walnut Rootstock. HortScience, 19, 507-509.

Elequisandra, C.A., João, P. R., Vanderley, J.P., Simone, A. A. \& Berildo, M. (2017). Salt concentrations in culture media for the development of Dipteryxalatain vitro. Brazillian Agricultural Research, 52(12): 1295-1300.

Fageria, N.K., Moreira, A., Moraes, L.A.C. \& Moraes, M.F. (2014). Root Growth, Nutrient Uptake, and Nutrient-Use Efficiency by Roots of Tropical Legume Cover Crops as Influenced by Phosphorus Fertilization, Communications in Soil Science and Plant Analysis, 45(5): 555-569.

Husain, M. K., Anis, M. \& Shahzad, A. (2008). In vitro propagation of a multipurpose leguminous tree (Pterocarpus marsupium
Roxb.) using nodal explants. Acta Physiologiae Plantarum, 30: 353-359

Jones, N. (1967). Storage of Cedrela odorata seeds. Forest Products Research Institute (FPRI) Technical Newsletter, 1(2): $24-25$.

Ken, F. (2019). Useful tropical Database. tropical.theferns.info/viewtropical.php?id= Cedrela+odorata. Date Assessed: 4/6/19.

Lloyd, G. \& McCown, B. (1980). Commerciallyfeasible micro-propagation of mountain laurel, Kalmia latifolia, by use of shoot-tip culture. Combined Proceedings/International Plant Propagators' Society, 30: S421-S427.

Maruyama, E. (2006). Tissue culture of Swietenia macrophylla King (Big-Leaf Mahogany). In: Suzuki, K., Ishii, K., Sakurai, S. and Sasaki S. (Eds) Plantation Technology in Tropical Forest Science. Springer-Verlag, Tokio, Japan, pp. 131-136.

Mazri, M.A. (2013). Effect of Basal Medium, Explants Size and Density on the In Vitro Proliferation and Growth of Date Palm (Phoenix dactylifera L.) Cultivar '16-bis'. Notulae Scientia Biologicae, 5(3): 332337.

Mcdonald, A.J.S. (1994). Nutrient supply and plant growth. In: Lumsden, P.J., Nicholas, J.R., Davies, W.J. (Eds.), Physiology, Growth and Development of Plants in Culture, Kluwer Academic Publishers, pp 47-57.

McGranahan, G.H., Driver, A. \& Tulecke, W. (1987). Tissue culture of Juglans. In: Bonga, G.M and Durzan, D.J. (Eds.) Cell and Tissue Culture in Forestry, Martinus Nijhoff, Dordrecht, 3:261-271.

Mohammad, M.A., Abbas, Y., Abdolali, S., Saber, S. \& Shoresh, M.G. (2014). Effects of nutrient media, different cytokinin types and their concentrations on in vitro multiplication of $\mathrm{G} \times \mathrm{N} 15$ (hybrid of almond $\mathrm{x}$ peach) vegetative rootstock. 
Journal of Genetic Engineering and Biotechnology, 12: 81-87.

Murashige, T. \& Skoog, E. (1962). A revised medium for rapid growth and bioassays with tobacco tissue cultures. Physiologia Plantarium, 15: 473-497.

Nitish, K. \& Reddy, M.P. (2011). In vitro propagation: A review. Journal of Forest Science, 27(2): 61-72.

Nunes, E., Castilho, C.V., Moreno, F.N. \& Viana, A.M. (2002). In vitro culture of Cedrela fissilis Vellozo (Meliaceae). Plant Cell, Tissue and Organ Culture, 70: 259-268.

Olorode, M.E., Nwogwugwu, J.O. \& Oladipo, A.D. (2018). In vitro Propagation of Cedrela odorata For Germplasm Conservation and Reforestation. International Journal of Applied Research and Technology, 7(11): 86-91.

Pennington, T.D. \& Muellner, A.N. (2010). A monograph of Cederela (Meliaceae) DH Books; The Manse, Milborne Port, England.p112.

Perez, J., Mesen, F., Aguila, M. \& Hilje, L. (2005). Development of a micropropagation method applicable to selected genotypes of Cedrela odorata L. development and rooting phases. Natural Resources and Environment, 46-47: 146-151.

Perez, J., Mesen, F., Aguilar, M. \& Hilje, L. (2002). Development of a micropropagation method applicable to selected genotypes of Cedrela odorata L. optimization of the multiplication phase. Magazine. Central American Forestry, 38: 67-71.

Perez-Salicrup, D. R. \& Esquivel, R. (2008). Tree infection by Hypsipyla grandella in Swietenia macrophylla and Cedrela odorata (Meliaceae) in Mexico's southern Yucatan Peninsula. Forest Ecology and Management, 255(2): 324-327.

Preece, J.E., Van Sambeek, J.W., Huetteman, C.A. \& Gaffney, G.R. (1989). Biotechnology: in-vitro studies with walnut (Juglans) species. In: Phelps, J.E. (Eds) The continuing quest for quality. Proceeding of 4th Black Walnut Symposium, Walnut Council, Indianapolis, pp 159-180.

Roberta, H.S. (2012). Media Components and Preparation. Plant Tissue Culture. Third Edition. pp 31-43.

Rolando, G., Miladys, D., Yailín, G., Aníbal, G., Miguel, G., Peter, D.S.C., Basilio, C. \& Karla, Q. (2011). In vitro propagation of cedar (Cedrela odorata L.) from juvenile shoots. Chilean Journal of Agricultural Research, 71(3): 376-382.

Schottz, E.S., Kalilfilho, A.N., Tracs, A.L., Koehler, H., Ribas, L.L. \& Quoirin, M. (2007). In vitro multiplication of Swietenia macrophylla King (Meliaceae) from juvenile shoots. Ciencia Forestal, 17(2):109-117.

Seema, U. \& Vijaya, K. (2015). Comparison of different medium and establishment of an efficient micropropagation technique of Clerodendrum serratum I. an endangered medicinal plant. IOSR Journal of Environmental Science, Toxicology and Food Technology, 1(2): 27-35.

Wang, Y., Thorup-Kristensen, K., Jensen, L.S. \& Magid, J. (2016). Vigorous root growth is a better indicator of early nutrient uptake than root hair traits in spring wheat grown under low fertility. Frontiers in Plant $\begin{array}{lll}\text { Science, } & 7 \text { : } & 865 .\end{array}$ 